\title{
Respon Pertumbuhan Bibit Kakao (Theobroma cacao L.) Terhadap Pemberian Kompos Limbah Kelapa Sawit
}

\author{
${ }^{1}$ Fico Ovender, ${ }^{* 2}$ Rudi Hartawan, dan ${ }^{3}$ Edy Marwan \\ ${ }^{1}$ Alumni Program Studi Agroteknologi, Fakultas Pertanian Universitas Batanghari \\ ${ }^{2}$ Program Studi Agroteknologi, Fakultas Pertanian Universitas Batanghari \\ J1. Slamet Riyadi-Broni, Jambi. 36122 Telp +62074160103 \\ ${ }^{3}$ Prodi Agribisnis Fakultas Pertanian Universitas Muhammadiyah Bengkulu \\ J1. Bali Bengkulu. 38119, Indonesia \\ *2 e mail korespondensi : rudi2810@yahoo.com
}

\begin{abstract}
Cacao (Theobroma cacao L.) is one of the important plantation commodities after oil palm and rubber. This plant has a high economic value and is a foreign exchange earner. The seeds produced are used as raw material for the foodstuff industry as well as for the pharmaceutical and cosmetic industries. Based on data from the Central Statistics Agency, the productivity of cocoa-farmers in Jambi is still very low, only reaching $585 \mathrm{~kg} \mathrm{ha}^{-1}$. This study aims to obtain a dose of oil palm waste compost to support the growth of cocoa seedlings. The experiment was carried out in Pijon Village, Jaluko District, Muaro Jambi Regency from December 2020 to April 2021. This experiment was carried out using a completely randomized design environment. The treatment design used was compost dosage consisting of 4 levels, namely $00=$ without giving compost, $p 1=5$

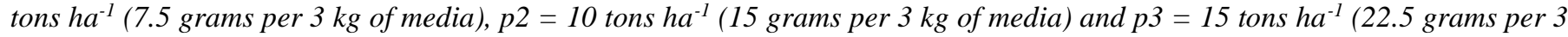
$\mathrm{kg}$ of media). The observed data were tabulated and analyzed with analysis of variance. If the calculated $F$ value has a significant effect, then the DNMRT further test for 95\% accuracy is carried out. The results showed that the application of compost 15 tons ha-1 showed an increase the plant height of $63.78 \%$, the stem diameter of $73.68 \%$, the shoot dry weight $30.83 \%$, the total dry weight $95.12 \%$, an the short root ratio $90.37 \%$.
\end{abstract}

Keywords : cocoa, compost, organic farming

Abstrak. Kakao (Theobroma cacao L.) adalah salah satu komoditas perkebunan yang penting setelah kelapa sawit, dan karet. Tanaman ini memiliki nilai ekonomis yang tinggi dan penghasil devisa negara. Biji yang dihasilkan digunakan sebagai bahan baku industri bahan makanan maupun industri farmasi dan kosmetik. Berdasarkan data dari Badan Pusat Statistik, produktivitas tanaman kakao petani di Jambi masih sangat rendah, hanya mencapai $585 \mathrm{~kg} \mathrm{ha}^{-1}$. Penelitian ini bertujuan untuk mendapatkan dosis kompos limbah kelapa sawit dalam mendukung pertumbuhan bibit kakao. Percobaan dilaksanakan di Desa Pijon, Kecamatan Jaluko, Kabupaten Muaro Jambi pada bulan Desember 2020 sampai April 2021. Percobaan ini dilakukan dengan menggunakan Rancangan Lingkungan Rancangan Acak Lengkap. Rancangan perlakuan yang digunakan adalah dosis pupuk kompos yang terdiri dari 4 taraf yaitu : p0 = Tanpa Pemberian Kompos, p1 = 5 ton ha ${ }^{-1}(7,5$ gram per $3 \mathrm{~kg}$ media), p2 = 10 ton $\mathrm{ha}^{-1}$ (15 gram per $3 \mathrm{~kg}$ media) dan $\mathrm{p} 3=15$ ton ha ${ }^{-1}$ ( 22,5 gram per $3 \mathrm{~kg}$ media). Data hasil pengamatan ditabulasi dan dianalisis dengan analisis ragam. Jika nilai $\mathrm{F}$ hitung berpengaruh nyata, maka dilakukan uji lanjut DNMRT ketelitian 95\%. Hasil penelitian menunjukkan bahwa pemberian kompos 15 ton ha-1 menunjukkan peningkatan tinggi tanaman sebesar 63,78\%, peningkatan diameter batang sebesar 73,68\%, peningkatan bobot kering tajuk 30,83\%, peningkatan berat kering total $95,12 \%$, peningkatan nisbah tajuk akar 90,37\%.

Kata kunci: kakao, kompos, pertanian organik

\section{PENDAHULUAN}

Kakao (Theobroma cacao L.) adalah komoditas perkebunan yang penting setelah kelapa sawit, dan karet. Tanaman ini memiliki nilai ekonomis yang tinggi dan penghasil devisa negara. Biji yang dihasilkan digunakan sebagai bahan baku industri bahan makanan maupun industri farmasi dan kosmetik. Berdasarkan data dari Badan Pusat Statistik (2018), produktivitas tanaman kakao petani di Jambi masih sangat rendah, hanya mencapai 585 $\mathrm{kg} \mathrm{ha}^{-1}$, padahal produktivitas di perkebunan swasta mencapai $865 \mathrm{~kg} \mathrm{ha}^{-1}$. Rendahnya produktivitas kakao petani disebabkan oleh beberapa hal antara lain, tidak menggunakan klon unggul, serangan hama dan penyakit serta penerapan teknik budidaya yang belum sesuai. Usaha yang dapat dilakukan untuk meningkatkan produktivitas kakao diawali dengan penyediaan bibit bermutu. Pembibitan merupakan pertumbuhan awal suatu tanaman sebagai penentu pertumbuhan selanjutnya maka pemeliharaan dalam pembibitan harus lebih intensif dan diperhatikan. Selain pemupukan, pertumbuhan bibit kakao juga dipengaruhi jenis tanah yang digunakan sebagai media.

Beberapa cara dapat dilakukan untuk menyiapkan bibit bermutu. Benih dari klon unggul ditanam pada media yang baik akan mendukung pertumbuhan dan peningkatan kualitas bibit. Pembibitan yang baik diharapkan dapat menghasilkan tanaman kakao berkualitas dan berproduksi tinggi (Siregar, Tumpal, Slamet dan Laeli, 2014) Salah satu cara penyediaan bibit bermutu adalah dengan memperhatikan media tanam. 
Media tanam yang baik dapat dibuat dari campuran tanah dan bahan organik. Bahan organik yang digunakan adalah kompos dari limbah kelapa sawit. Menurut Hannum, Hanum, dan Ginting (2014) pencemaran yang disebabkan oleh industri kelapa sawit dan potensi bahan organik yang terkandung dalam limbah kelapa sawit, menuntut suatu perkebunan kelapa sawit dalam mengelola limbah tesebut.

Hasil penelitian Rona, Widowati, dan Sutoyo (2014), menunjukkan bahwa pemberian kompos 12,5 ton ha-1 secara berkelanjutan dapat meningkatkan pertumbuhan bunga menjadi buah tanaman cabai. Menurut Minarsih (2013), perlakuan tanpa kompos kulit buah kakao dalam media tanam menghasilkan pertumbuhan bibit tanaman kakao namun tidak berbeda nyata dengan campuran kompos kulit buah kakao sebanyak 12,5\%. Berdasarkan penelitian Rahman dan Nurrurrahmah (2016), mengatakan bahwa tanaman bawang merah setelah pemberian limbah padat dan cair kelapa sawit tersebut kemungkinan besar akan memberikan pertumbuhan yang lebih baik terhadap aspek agronominya termasuk tinggi tanaman dan jumlah anakannya jika faktor iklim mendukung.

Hasil penelitian di atas menggambarkan bahwa penambahan kompos pada media tanam dapat meningkatkan kandungan bahan organik tanah sehingga kesuburan tanah menjadi lebih baik. Bahan organik memiliki peran untuk meningkatkan daya pegang air, meningkatkan ketersediaan unsur hara dan memperbaiki struktur tanah. Penggunaan kompos limbah kelapa sawit diharapkan dapat menggemburkan tanah meningkatkan ketersediaan air tanah, menyumburkan biologi tanah sehingga tercipta media tumbuh yang mendukung pertumbuhan bibit kakao.

Penggunaan limbah kelapa sawit memerlukan pengkajian tentang berapa banyak atau berapa besar dosis yang akan digunakan. Melalui penelitian ini akan dicari dosis kompos limbah kelapa sawit yang terbaik yang akan mendukung pertumbuhan bibit kakao.

\section{METODE PENELITIAN}

Percobaan lapangan dilaksanakan di Kampus II Universitas Batanghari, Desa Pijoan, Kecamatan Jaluko, Kabupaten Muaro Jambi, Provinsi Jambi pada bulan Desember 2020 sampai April 2021. Analisis tanaman dilaksanakan di Laboratorium Dasar Fakultas Pertanian dan Analisis kompos dilaksanakan di Laboratorium Kimia dan Kesuburan Tanah, Universitas Jambi.

Bahan yang digunakan adalah buah kakao jenis Forastero yang di Balai Pembibitan Tanaman Perkebunan, Dinas Perkebunan Provinsi Jambi Jalan raya Jambi-Bulian Km 10. Kompos berbahan baku limbah kelapa sawit dengan komposisi abu sawit 20\%, tankos 30\%, pelepah sawit 20\% dan kotoran sapi 30\%. Total bobot bahan yang digunakan adalah $50 \mathrm{~kg}$. Pengomposan dilakukan dengan metode wind row system (Irvan, Mahardela dan Trisakti, 2014) yang dilakukan sebagai berikut: Limbah kelapa sawit terlebih dahulu disusun dan diatasnya ditaburkan kotoran sapi. Tinggi tumpukan 0,75 m dan lebar tumpukan $1 \mathrm{~m}$. Larutan EM4 sesuai perlakuan disiramkan pada tumpukan bahan kompos. Selanjutnya tumpakan bahan ditutup dengan plastik. Pengadukan dilakukan secara berkala setiap 15 hari. Lama pengomposan dilakukan selama 60 hari. Peralatan yang digunakan cangkul, meteran, mistar, ember, timbangan analitik, jangka sorong, hand sprayer, oven listrik, seperangkat alat untuk membuat naungan dan alat tulis.

Percobaan ini dilakukan dengan menggunakan rancangan lingkungan acak lengkap. Rancangan perlakuan yang digunakan adalah dosis pupuk kompos yang terdiri dari 4 taraf yaitu : $\mathrm{p} 0=$ Tanpa Pemberian Kompos, $\mathrm{p} 1=5$ ton per ha $(7,5$ gram per $3 \mathrm{~kg}$ media), $\mathrm{p} 2=10$ ton per ha ( 15 gram per $3 \mathrm{~kg}$ media) dan $\mathrm{p} 3=15$ ton per ha $(22,5$ gram per $3 \mathrm{~kg}$ media). Percobaan diulang sebanyak 3 kali dengan masing-masing petak terdapat 10 bibit kakao. Sebanyak 7 bibit dijadikan sampel untuk pengamatan pertumbuhan tanaman.

Bibit kakao dilindungi dengan naungan ukuran $6 \mathrm{~m}$ x $6 \mathrm{~m}$. Atap yang digunakan adalah paranet satu lapis (menahan sinar matahari sebesar 25\%). Media Tanam yang digunakan adalah lapisan tanah topsoil dengan kedalaman $0-20 \mathrm{~cm}$. Media tanam dicampur dengan pupuk kompos sesuai dengan perlakuan. Polibag yang digunakan berukuran $20 \times 30 \mathrm{~cm}$ dan diisi dengan $3 \mathrm{~kg}$ tanah. Jumlah kompos yang ditambahkan pada media disesuaikan dengan perlakuan. Media tanaman ini disiapkan 1 minggu sebelum tanam dengan tujuan bahan organik terdekomposisi dan menyediakan unsur hara.

Benih diambil dari buah bagian tengah yang masak dari tanaman yang telah cukup umur. Sebelum dikecambahkan benih harus dibersihkan terlebih dulu daging buahnya dengan abu sekam. Benih kakao dikecambahkan pada media pasir yang telah disiapkan. Kecambah dipelihara selama 7 hari pada media berkecambahan. Kecambah diseleksi dan disiapkan sebanyak 120 tanaman yang akan dipelihara pada media polybag. Setelah kecambah berumur 7 hari dipindahkan pada polibag yang telah diisi media tanamnya sesuai dengan perlakuan. Kegiatan yang dilakukan dalam pemeliharaan ini antara lain penyiraman, penyiangan, dan pengendalian hama dan penyakit. 


\section{Parameter yang diamati adalah :}

1. Tinggi Tanaman $(\mathrm{cm})$ : Pengukuran tinggi tanaman dimulai dari $1 \mathrm{~cm}$ di atas permukaan tanah dengan menggunakan mistar. Pengukuran dilakukan dengan interval 2 minggu sampai tanaman berumur 3 bulan. Data mingguan disajikan dalam grafik.

2. Diameter Batang $(\mathrm{mm})$ : Pengamatan diameter bibit diukur dengan sejajar garis $1 \mathrm{~cm}$ diatas garis permukaan tanah dengan menggunakan jangka sorong. Pengukuran dilakukan pada satu bagian sisi batang yang diukur diametenya. Pengamatan ini dilakukan dengan interval 2 minggu sekali sampai akhir penelitian. Data mingguan dibuat grafik.

3. Bobot Kering Tajuk (g): Bobot kering tajuk diperoleh dengan cara menimbang bagian tajuk tanaman mulai dari leher akar sampai ke pucuk yang telah dikering ovenkan pada suhu $100^{\circ} \mathrm{C}$ selama 48 jam. Pengukuran bobot kering tajuk dilakukan di akhir penelitian.

4. Bobot Kering Total (g): Pengamatan dilakukan pada akhir penelitian. Sampel tanaman dimasukkan dalam amplop kertas yang telah diberi label lalu dioven pada suhu $105^{\circ}$ selama $48 \mathrm{jam}$. Sampel dimasukan dalam desikator sampai dingin lalu bobot kering total ditimbang dengan timbangan analitik sampai diperoleh berat konstan.

5. Nisbah Tajuk Akar: Pengamatan dilakukan pada akhir penelitianya itu dengan membongkar tanaman sampel lalu dibersihkan dengan air sampai bersih,kemudian dipotong bagian tunas dan bagian akar tanaman kemudian dikeringkan dengan oven pada suhu $105^{\circ} \mathrm{C}$ selama $2 \times 24$ jam.

Data hasil pengamatan ditabulasi dan dianalisis dengan analisis ragam. Jika nilai $\mathrm{F}$ hitung berpengaruh nyata, maka dilakukan uji lanjut DNMRT ketelitian 95\%. Data dinamika pertumbuhan tinggi tanaman dan diameter batang disajikan dalam bentuk grafik.

\section{Kualitas Kompos}

\section{HASIL DAN PEMBAHASAN}

Penggunaan kompos merupakan upaya untuk mengurangi dampak negatif penggunaan pupuk anorganik demi mewujudkan pertanian yang berwawasan lingkungan. Hasil Analisis dari Laboratorium Kimia dan Kesuburan Tanah Fakultas Pertanian Universitas Jambi (2020), Kompos limbah kelapa sawit memiliki kandungan hara berdasarkan pada tabel 1 .

Tabel 1. Hasil analisis laboratorium kandungan hara kompos

\begin{tabular}{llcccc}
\hline \multicolumn{1}{c}{ Parameter } & \multicolumn{1}{c}{ Metode } & Hasil Analisis & Satuan & SNI: 19-7030-2004 & Keterangan \\
\hline $\mathrm{pH}$ & pH meter & 7,81 & - & $6,8-7,49$ & Lebih tinggi \\
Kadar air & Oven & 33,55 & $\%$ & Max. 50 & Lebih rendah \\
$\mathrm{P}_{2} \mathrm{O}_{5}$ & Spektro FM & 0,82 & $\%$ & Min. 0,1 & Lebih tinggi \\
$\mathrm{K}_{2} \mathrm{O}$ & Flame & 0,75 & $\%$ & Min. 0,2 & Lebih tinggi \\
$\mathrm{N}$-total & Kjeldhal & 0,78 & $\%$ & Min. 0,4 & Lebih tinggi \\
C-organik & Spektro & 12,5 & $\%$ & $9,8-32$ & Lebih rendah \\
$\mathrm{C} / \mathrm{N}$ & Kjeldhal & 16 & - & $10-20$ & Sesuai \\
\hline
\end{tabular}

Hasil Analisis menunjukan kompos limbah kelapa sawit memiliki kandungan berupa kadar air=33,55\%, $\mathrm{pH}=$ $7,81, \mathrm{C}$-organik $=12,50 \%, \mathrm{~N}$-Total $=0,78 \%, \mathrm{C} / \mathrm{N}=16, \mathrm{P}$ total $=0,82 \%, \mathrm{~K}$ total $=0,75 \%$. Kadar air yang diperoleh sampel yaitu sebesar 33,55 \%, hasil ini menunjukkan bahwa kadar air pada sampel mencapai selisih 16,45\% dari standar kadar air pupuk organik maksimal $50 \%$. Berdasarkan SNI 19-7030-2004, kadar air yang diperbolehkan dalam kompos/pupuk organik maksimal $50 \%$.

Berdasarkan hasil analisis sampel kompos nilai pH sebesar 7,81. Hasil ini menunjukkan bahwa nilai pH dari sampel kompos LKS bersifat basa. Jika $\mathrm{pH}$ basa meningkat maka aktivitas mikroorganisme semakin menurun. Kenaikan $\mathrm{pH}$ diakibatkan oleh kegiatan mikroorganisme yang tidak lagi melakukan perombakan bahan organik senyawa karbon menjadi asam organik. Sedangkan penurunan nilai $\mathrm{pH}$ terjadi karena adanya reaksi reduksi yang mengikat oksigen. Proses ini akan meningkatkan aktivitas mikroorganisme dan menghasilkan asam organik, yang dapat menyebabkan pH menjadi turun (Ismayana, Indrasti, Maddu, Fredy, 2012). Kisaran pH pada akhir pengomposan adalah $5,16-8,7$. Nilai $\mathrm{pH}$ pada kisaran tersebut berada pada kisaran $\mathrm{pH}$ minimum berdasarkan persyaratan teknis minimal pupuk organik yaitu $4-8$ (BSN, 2004).

Hasil analisis sampel kompos menunjukkan bahwa nilai $\mathrm{C} / \mathrm{N}$ rasio dari kompos LKS adalah 16. Bahan organik limbah kelapa sawit berupa $20 \%$ abu boiler, $30 \%$ tankos, $20 \%$ pelepah sawit dan $30 \%$ kotoran sapi yang telah diolah oleh kelompok tani Suka Maju sudah terdekomposisi dan menyediakan unsur hara bagi tanaman. Bahan organik yang dapat dimanfaatkan oleh tanaman adalah bahan organik yang memiliki nilai $\mathrm{C} / \mathrm{N}$ rasio yang hampir 
Fico Ovender, Rudi Hartawan, dan Edy Marwan. Respon Pertumbuhan Bibit Kakao (Theobroma cacao L.) Terhadap Pemberian Kompos Limbah Kelapa Sawit

sama dengan tanah, yaitu kurang dari 20 (Siboro, Surya, dan Herlina, 2013). Surtinah (2013) menambahkan bahwa semakin rendah nilai $\mathrm{C} / \mathrm{N}$ rasio pada kompos maka semakin banyak hara yang tersedia bagi tanaman untuk mencukupi kebutuhan hidupnya.

\section{Pertumbuhan Bibit Tanaman Kakao}

Bibit tanaman kakao menunjukkan respon yang positif terhadap penambahan kompos pada media tumbuh. Hasil analisis ragam secara umum menunjukkan bahwa pemberian kompos berpengaruh nyata terhadap parameter tinggi tanaman, diameter tanaman, berat kering tajuk, berat kering total dan nisbah tajuk akar.

Tabel 2. Rata-rata tinggi tanaman kakao, diameter batang, berat kering tajuk, bobot kering total dan nisbah tajuk akar pada pemberian kompos limbah kelapa sawit

\begin{tabular}{cccccc}
\hline $\begin{array}{c}\text { Perlakuan Kompos } \\
\begin{array}{c}\text { Limbah Kelapa } \\
\text { Sawit (ton ha- })\end{array}\end{array}$ & $\begin{array}{c}\text { Rata-Rata Tinggi } \\
\text { Tanaman }(\mathrm{cm})\end{array}$ & $\begin{array}{c}\text { Rata-Rata Diameter } \\
\text { Tanaman }(\mathrm{mm})\end{array}$ & $\begin{array}{c}\text { Berat Kering } \\
\text { Tajuk }(\mathrm{g})\end{array}$ & $\begin{array}{c}\text { Berat Kering } \\
\text { Total }(\mathrm{g})\end{array}$ & $\begin{array}{c}\text { Nisbah Tajuk } \\
\text { Akar }\end{array}$ \\
\hline p0 & $21,37 \mathrm{a}$ & $4,75 \mathrm{a}$ & $2,87 \mathrm{a}$ & $2,87 \mathrm{a}$ & $2,18 \mathrm{a}$ \\
p1 & $26,40 \mathrm{~b}$ & $5,60 \mathrm{a}$ & $3,03 \mathrm{ab}$ & $4,28 \mathrm{a}$ & $2,46 \mathrm{a}$ \\
p2 & $34,00 \mathrm{c}$ & $8,03 \mathrm{~b}$ & $3,24 \mathrm{~b}$ & $4,54 \mathrm{~b}$ & $3,98 \mathrm{~b}$ \\
p3 & $35,00 \mathrm{c}$ & $8,25 \mathrm{~b}$ & $3,28 \mathrm{~b}$ & $5,60 \mathrm{c}$ & $4,15 \mathrm{~b}$ \\
\hline
\end{tabular}

Keterangan : Angka- angka yang diikuti oleh huruf kecil yang sama berbeda tidak nyata pada taraf $\alpha 5 \%$ menurut uji DNMRT

Tabel 2 menunjukkan peningkatan perlakuan kompos akan meningkatkan nilai tinggi tanaman, diameter tanaman, berat kering tajuk, total dan nisbah tajuk akar. Pada perlakuan kontrol tinggi tanaman sebesar 21,37 cm, berbeda nyata dengan perlakuan $\mathrm{p}_{1}(26,40 \mathrm{~cm}), \mathrm{p}_{2}(34 \mathrm{~cm})$ dan $\mathrm{p}_{3}(35 \mathrm{~cm})$. Tanaman terendah diperoleh pada kontrol yaitu sebesar 21,37 cm dan tertinggi diperoleh data perlakuan $\mathrm{p}_{3}$ sebesar $35 \mathrm{~cm}$. Peningkatan tinggi tanaman bibit kakao setelah perlakuan kompos sebesar 15 ton ha-1 sebesar 63,78\%. Pada perlakuan kontrol diameter batang sebesar $4,75 \mathrm{~mm}$, berbeda nyata dengan perlakuan $\mathrm{p}_{2}(8,03 \mathrm{~mm})$ dan $\mathrm{p}_{3}(8,25 \mathrm{~mm})$ tetapi berbeda tidak nyata dengan perlakuan $\mathrm{p}_{1}(5,60 \mathrm{~mm})$. Diameter batang terendah diperoleh pada yaitu sebesar $\mathrm{p}_{0}(4,75 \mathrm{~mm})$ dan diameter batang tertinggi diperoleh dari perlakuan $\mathrm{p}_{3}$ sebesar $8,25 \mathrm{~mm}$. Peningkatan diameter batang bibit kakao setelah perlakuan kompos sebesar 15 ton ha-1 sebesar 73,68\%. Perlakuan kontrol bobot kering tajuk sebesar 2,73 g, berbeda nyata dengan perlakuan $\mathrm{P}_{2}(3,24 \mathrm{~g})$ dan $\mathrm{P}_{3}(3,28 \mathrm{~g})$ tetapi berbeda nyata pada perlakuan $\mathrm{P}_{1}(3,03 \mathrm{~g})$. Bobot kering tajuk terendah diperoleh pada kontrol sebesar 2,73 g dan bobot kering tajuk tertinggi dari perlakuan $\mathrm{p}_{3}$ sebesar 3,28 $\mathrm{g}$. Peningkatan bobot kering total bibit kakao setelah perlakuan kompos sebesar 15 ton ha ${ }^{-1}$ sebesar 20,15\%. Perlakuan kontrol bobot kering total sebesar 2,87 g, berbeda nyata dengan perlakuan $\mathrm{P}_{2}(4,54 \mathrm{~g})$ dan $\mathrm{P}_{3}(5,60 \mathrm{~g})$ tetapi berbeda nyata pada perlakuan $\mathrm{P}_{1}(3,03 \mathrm{~g})$. Bobot kering total terendah diperoleh pada kontrol sebesar 2,87 $\mathrm{g}$ dan bobot kering total tertinggi dari perlakuan $\mathrm{p}_{3}$ sebesar 5,60 g. Peningkatan bobot kering total bibit kakao setelah perlakuan kompos sebesar 15 ton ha $^{-1}$ sebesar $95,12 \%$. Pada perlakuan kontrol nisbah tajuk akar sebesar 2,18, berbeda nyata dengan perlakuan $\mathrm{p}_{2}(3,98)$ dan $\mathrm{p}_{3}(4,15)$ tertapi tidak berbeda nyata pada perlakuan $\mathrm{P}_{1}(2,46)$. Nisbah tajuk akar terendah diperoleh pada kontrol sebesar 2,18 dan nilai tertinggi pada perlakuan $\mathrm{p}_{3}$ sebesar 4,15. Peningkatan nisbah tajuk akar bibit kakao setelah perlakuan kompos sebesar 15 ton ha ${ }^{-1}$ sebesar 90,37\%.

Perkembangan tinggi tanaman dalam pengamatan interval 2 minggu menunjukkan perubahan tinggi yang pesat mulai terjadi pada minggu ke 8 . Grafik pergerakan data tinggi tanaman disajikan pada Gambar 1.

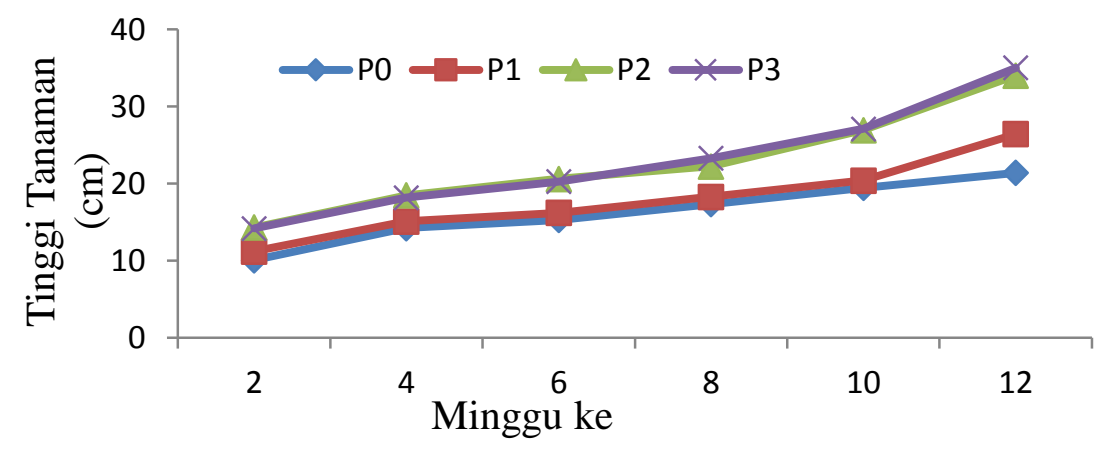

Gambar 1. Perkembangan tinggi tanaman kakao selama 12 minggu 
Pada Gambar 1 dapat dilihat pertumbuhan tinggi tanaman kakao dari pemberian kompos limbah kelapa sawit data minggu ke 2 sampai minggu ke 12 pada perlakuan $\mathrm{p}_{2}$ dan $\mathrm{p}_{3}$ relatif hampir sama. Pada minggu ke 2 sampai minggu ke 12 setelah tanam, $\mathrm{p}_{3}$ memperlihatkan pertumbuhan tinggi yang lebih baik dibandingkan dengan perlakuan lainnya.

Pemberian kompos limbah kelapa sawit mampu memperbaiki kesuburan tanah, meningkatkan daya pegang air dan menyediakan unsur hara. Thabrani (2011) menyatakan bahwa bahan organik akan meningkatkan aktifitas biologi tanah dan kegiatan jasad mikro dalam membantu proses dekomposisi. Bahan organik yang terkandung didalam kompos limbah kelapa sawit memiliki peran untuk meningkatkan daya pegang air, meningkatkan ketersediaan unsur hara dan memperbaiki struktur tanah.

Dari hasil pengamatan Tabel 2 dan Gambar 1 diketahui bahwa rata-rata nilai tertinggi tinggi tanaman diperoleh pada perlakuan $\mathrm{p}_{3}(35 \mathrm{~cm})$ dan nilai terendah diperoleh pada $\mathrm{p}_{0}(21,37 \mathrm{~cm})$, dengan persentase peningkatan $63,78 \%$. Peningkatan tinggi tanaman sangat dipengaruhi oleh faktor lingkungan salah satunya adalah ketersediaan unsur hara yang dibutuhkan tanaman dalam keadaan optimal. Pemberian kompos 15 ton ha ${ }^{-1}\left(\mathrm{p}_{3}\right)$ dapat memperbaiki sifat fisik tanah sehingga dapat memberi kesempatan pertumbuhan akar lebih baik dan kandungan unsur hara NPK yang cukup. Menurut Hasibuan, Saputra., dan Nurbaiti (2014) menyatakan bahwa unsur N, P, dan K merupakan unsur hara esensial yang sangat dibutuhkan oleh tanaman misalnya Nitrogen mempunyai peran utama untuk merangsang pertumbuhan secara keseluruhan diantaranya untuk pertumbuhan batang yang dapat memacu pertumbuhan tinggi tanaman.

Perlakuan tanpa pemberian kompos limbah kelapa sawit cenderung menunjukkan tinggi tanaman yang lebih rendah bila dibandingkan dengan pemberian kompos limbah kelapa sawit. Terjadi perbedaan tinggi tanaman dikarenakan jumlah kandungan NPK pada $\mathrm{p}_{1}$ masih lebih rendah dibandingkan dengan perlakuan $\mathrm{p}_{2}$ dan $\mathrm{p}_{3}$ sehingga kandungan 15 ton $\mathrm{ha}^{-1}$ dapat mendukung pertumbuhan bibit kakao dengan optimum. Perlakuan Kompos LKS berpengaruh nyata terhadap tinggi tanaman kakao. Unsur hara NPK pada kompos limbah kelapa sawit sudah terpenuhi untuk pertumbuhan bibit kakao.

Perkembangan diameter batang dalam pengamatan interval 2 minggu menunjukkan perubahan diameter batang yang pesat mulai terjadi pada minggu ke 8. Grafik perkembangan diameter batang disajikan pada Gambar 2.

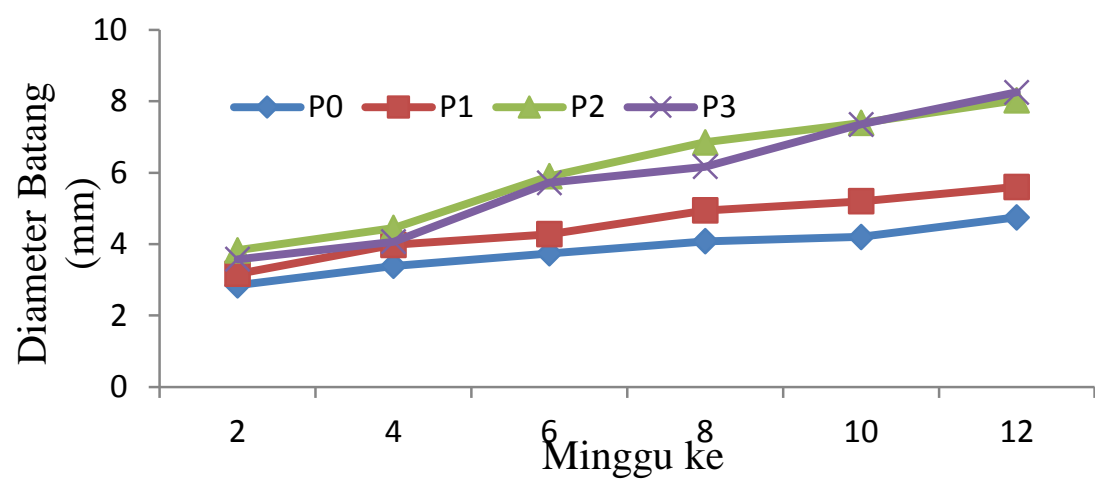

Gambar 2. Perkembangan diameter batang kakao selama 12 minggu

Pada Gambar 2 dapat dilihat perkembangan diameter batang kakao dari pemberian kompos limbah kelapa sawit pada minggu ke 2 sampai minggu ke 12 perkembangan diameter batang pada perlakuan $\mathrm{p}_{2}$ dan $\mathrm{p}_{3}$ relatif hampir sama. Pada minggu ke 2 sampai minggu ke 12 setelah tanam $\mathrm{p}_{3}$ memperlihatkan perkembangan diameter batang yang lebih baik dibandingkan dengan perlakuan lainnya.

Pemberian kompos LKS memberikan hasil yang berpengaruh nyata terhadap diameter batang, peningkatan diameter batang disebabkan karena aktivitas kambium yang meningkat. Kambium ini berkembang pesat terhadap diameter batang tanaman. Kompos limbah kelapa sawit mampu memberikan ketersedian unsur hara bagi tanaman untuk pertumbuhan diameter batang. Hasil pengamatan diameter batang yang dirangkum pada Tabel 2 dan Gambar 2, menunjukan rata-rata nilai tertinggi diperoleh pada perlakuan $\mathrm{p}_{3}(8,25 \mathrm{~mm})$ dan nilai terendah diperoleh pada $\mathrm{p}_{0}(4,75 \mathrm{~mm})$, dengan persentase peningkatan 73,68\%. Peningkatan diameter batang dipengaruhi oleh keberadaan unsur hara dan penyerapan air di dalam tanah. Unsur hara berperan dalam meningkatkan pertumbuhan diameter batang tanaman kakao sehingga terbentuknya jaringan dan organ tanaman. Menurut Buwono dan Ariani (2016) unsur K berperan mempercepat pertumbuhan jaringan meristematik terutama batang tanaman, mengguat batang sehingga tidak mudah rebah. $\mathrm{K}$ juga penting dalam fotosintesis dimana semakin meningkatnya fotosintesis pada tanaman akan menambah ukuran diameter batang. Hal ini sejalan dengan Mudyantini (2008), menyatakan bahwa besarnya diameter batang merupakan proses pertumbuhan dari hasil pembesaran dan diferensiasi 
sel. Hal ini dipengaruhi oleh penyerapan air $\left(\mathrm{H}_{2} \mathrm{O}\right)$ dan unsur hara dari dalam tanah oleh tanaman untuk terbentuknya jaringan-jaringan dan organ tanaman. Selain itu dipengaruhi juga oleh proses fotosintesis yang akan menghasilkan akumulasi fotosintat dalam organ tanaman.

Pada parameter bobot kering tajuk, rata-rata nilai tertinggi diperoleh pada perlakuan p3 (3,28 g) dan nilai terendah diperoleh pada $\mathrm{p}_{0}(2,73 \mathrm{~g})$, dengan persentase peningkatan 20,15\% (Tabel 2). Peningkatan bobot kering tajuk dipengaruhi oleh jumlah daun, karena daun merupakan tempat akumulasi hasil fotosintat tanaman. Adanya peningkatan proses fotosintesis akan meningkatkan pula hasil fotosintesis berupa senyawa- senyawa organik yang akan ditranslokasikan ke seluruh organ tanaman dan berpengaruh terhadap berat kering tajuk tanaman (Nurdin, 2011). Hasil berat kering merupakan keseimbangan antara fotosintesis dan respirasi. Fotosintesis akan meningkatkan berat kering karena pengambilan $\mathrm{CO}_{2}$ sedangkan respirasi mengakibatkan penurunan berat kering karena pengeluaran $\mathrm{CO}_{2}$. Ini menunjukkan bahwa kebutuhan energi dan ketersediaan oksigen dalam sel juga mempengaruhi fotorespirasi. Akibat fotorespirasi, fotosintesis menjadi jauh lebih rendah daripada seharusnya. Namun, fotorespirasi diketahui juga menjadi pemasukan beberapa komponen dasar proses fotosintesis. Dengan adanya fotorespirasi, jaringan tumbuhan lebih terjaga keseimbangannya.

Bertambahnya bobot kering total dipengaruhi oleh unsur hara Nitrogen, Pospor dan K dari Kompos LKS serta fotosintesis sehingga memberikan kontribusi terhadap peningkatan bobot kering total tanaman. Menurut Kharisma (2006), bobot kering akan meningkat dengan semakin bertambahnya kandungan nitrogen, pospor dan kalium dalam tanah. Rita (2014), menyatakan bahwa $90 \%$ bobot kering total adalah hasil fotosintesis. Pemberian kompos 15 ton ha $^{-1}$ (p3) memiliki kandungan unsur hara yang dapat mendukung proses fotosintesis pada pertumbuhan bibit kakao. Perlakuan 15 ton ha ${ }^{-1}$ menghasilkan pertumbuhan terbaik pada bobot kering total sebesar 5,60 g dengan persentase peningkatan 95,12\%.

Pada parameter nisbah tajuk akar, rata-rata nilai tertinggi diperoleh pada perlakuan p3 $(4,15)$ dan nilai terendah diperoleh pada $p_{0}(2,18)$, dengan persentase peningkatan 90,37\%. Perlakuan kompos LKS sangat mendukung pertumbuhan bibit kakao dalam penyerapan unsur hara serta proses metabolisme sehingga memberikan hasil yang tinggi pada parameter nisbah tajuk akar. Tajuk yang berkembang pesat sangat menentukan peningkatan nilai nisbah tajuk akar bibit kakao. Nilai nisbah tajuk akar yang tinggi menunjukkan perkembangan tajuk yang sangat pesat, dan pada saat bersamaan perkembangan akar tidak secepat perkembangan tajuk. Menurut Saragih dan Ardian (2017), menyatakan bahwa nisbah tajuk akar merupakan faktor penting dalam pertumbuhan yang mencerminkan kemampuan dalam penyerapan unsur hara serta proses metabolisme yang terjadi pada tanaman yang ditunjukkan dengan perkembangan tajuk.

Kompos limbah kelapa sawit memiliki manfaat untuk meningkatkan kandungan bahan organik tanah sehingga kesuburan tanah menjadi lebih baik. Bahan organik memiliki peran untuk meningkatkan daya pegang air dan kesuburan tanah sehingga meningkatkan ketersediaan unsur hara. Penggunaan kompos LKS sampai 15 ton ha ${ }^{-1}$ diharapkan dapat menggemburkan tanah, meningkatkan ketersediaan air tanah, biologi tanah sehingga tercipta media tumbuh yang mendukung pertumbuhan bibit kakao. Hal ini sejalan dengan Oviasogie, Odewale, Aisueni, Eguagie, Brown, dan Okoh (2013), bahwa beberapa keuntungan dari pupuk organik yaitu mengemburkan tanah, meningkatkan hasil panen, tanaman tumbuh lebih besar, lebih ramah lingkungan dengan proses daur ulang, mengurangi penumpukan limbah, meminimalkan emisi gas, melindungi tanaman dari penyakit tertentu, aman dan lebih murah dari pada pupuk kimia. Perlakuan $\mathrm{p}_{0}$ (tanpa pemberian kompos limbah kelapa sawit) menunjukan hasil yang kurang baik. Tanaman ini tidak tumbuh dengan baik karena unsur hara dan kondisi media lainnya yang dibutuhkan oleh tanaman tidak optimal.

\section{KESIMPULAN}

Dari penelitian yang telah dilaksanakan dapat diambil kesimpulan sebagai berikut; Perlakuan kompos limbah kelapa sawit berpengaruh nyata terhadap parameter tinggi tanaman, diameter batang, bobot kering tajuk, bobot kering total tanaman dan nisbah tajuk akar, pemberian kompos 15 ton ha $^{-1}$ menunjukkan peningkatan tinggi tanaman sebesar $63,78 \%$, peningkatan diameter batang sebesar 73,68\%, peningkatan bobot kering tajuk 30,83\%, peningkatan berat kering total $95,12 \%$, peningkatan nisbah tajuk akar $90,37 \%$.

\section{Badan Pusat Statistik. 2018. Produksi Perkebunan Menurut Provinsi dan Jenis Tanaman http://www.bps.go.id/linkTabel Statis/view/id/1672. Diakses pada tanggal 28 Maret 2019.}

[BSN]. Badan Standarisasi Nasional. 2004. Standar Nasional Indonesia 19-70302004 Tentang Spesifikasi Kompos dari Sampah Organik Domestik. Jakarta

Buwono, G. R., dan E. Ariani. 2016. Pertumbuhan Bibit Kakao (Theobroma cacao L.) Dengan Pemberian Abu Janjang Kelapa Sawit dan Pupuk NPK Pada Media Gambut. Jurnal JOM. 3 (2): 30-41 
Fico Ovender, Rudi Hartawan, dan Edy Marwan. Respon Pertumbuhan Bibit Kakao (Theobroma cacao L.) Terhadap

Hannum, J., C. Hanum., dan J.Ginting. 2014. Kadar N, P daun dan produksi kelapa sawit melalui penempatan TKKS pada rorak. Jurnal Online Agroekoteknologi. 2 (4): 1.279-1.286

Hasibuan, S., S. I. Saputra., dan Nurbaiti. 2014 Pengaruh Kompos Tandan Kosong Kelapa Sawit dan Pupuk NPK Terhadap Pertumbuhan Bibit Kakao (Theobroma cacao L.). Jurnal JOM. 1 (2): 1.561-1.571

Irvan, P. Mahardela dan B. Trisakti. 2014. Pengaruh Penambahan berbagai aktivator dalam proses pengomposan sekam padi (Oryza sativa). Jurnal Teknik Kimia USU. 30 (2): 15-24

Ismayana A, N.S. Indrasti, A. Maddu, A. Fredy. 2012. Faktor rasio C/N awal dan laju aerasi pada proses cocomposting bagasse dan blotong. J Teknol Indust Pangan Pertanian. 22 (3): 173-179.

Kharisma, R.A. 2006. Pengaruh Penambahan Bahan Aktif EM 4 dan Kotoran Ayam pada Kompos Alang-Alang (Imperata cylindrica) terhadap pertumbuhan Semai Gmelina Arborea. Skripsi. Fakultas Kehutanan Institut Pertanian Bogor.

Minarsih, 2013. Pengaruh Pemberian Kompos Kulit Buah Kakao Sebagai Campuran Media Pembibitan Dan Pupuk NPK (15:15:15) Terhadap Pertumbuhan Bibit Kakao (Theobromacacao L.) Jurnal Agrotek Tropika 1 (2) : 188 $-193$.

Nurdin E. 2011. Manajemen Sapi Perah. Graha Ilmu. Yogyakarta

Oviasogie, P. O., Odewale, J. O., Aisueni, N. O., Eguagie, E. I., Brown, dan E. Okoh (2013). Production, utilization and acceptability of organic fertilizers using palms and shea tree as sources of biomass. African Journal of Agricultural Research. 8 (27): 3.483-3.494.

Rahman, H.R. dan Nurrurahman. 2016. Efektifitas Limbah Padat dan Cair Kelapa Sawit serta Ampas Sagu Terhadap Tanaman Bawang Merah. Jurnal Universitas Cokoaminoto Palopo. 2 (1): 25-34

Rita, N.D. 2014. Pengaruh Kompos Terhadap Pengurangan Penggunaan Pupuk Anorganik Pada Sawi Putih ( Brassica Pekinensis) Di Lahan Kering. Media Bina Ilmiah. 8 (6) : 46-53.

Rona. Y., Widowati, dan Sutoyo. 2014. Penggunaan Kompos dan Biochar untuk Pertumbuhan dan Hasil Cabai Rawit (Capsicum frutenscen L). Malang: Program Studi Agroteknologi, Fakultas Pertanian, Universitas Thribhuwana Tunggadewi Malang.

Saragih, D. P. dan Ardian. 2017. Pengaruh Pemberian Kompos Kulit Buah Kakao Terhadap Pertumbuhan Bibit Kakao Hibrida (Theobroma cacao L.). JOM Faperta. 4 (2): 1.115-1.125

Siboro ES, E. Surya, dan N. Herlina. 2013. Pembuatan pupuk cair dan biogas dari campuran limbah sayuran. J. Teknik Kimia. 2(3): 40-43.

Sinaga, D. 2009. Pembuatan Pupuk Cair Dari Sampah Organik Dengan Menggunakan Biosca Sebagai Starter. Thesis. Sumatra Utara: Fakultas Pertanian Universitas Sumatra Utara.

Siregar, H. S.Tumpal., R. Slamet., dan N. Laeli. 2014. Budidaya Cokelat. Penebar Swadaya. Jakarta.

Surtinah. 2013. Pengujian kandungan unsur hara dalam kompos yang berasal dari serasah tanaman jagung manis (Zea mays saccharata). J. Ilmiah Pertanian. 11(1): 16-25.

Thabrani, A. 2011. Pemanfaatan Kompos Ampas Tahu untuk Pertumbuhan Bibit Kelapa Sawit (Elaeis guineensis Jacq). Skripsi Fakultas Pertanian Universitas Riau, Pekanbaru. 